\title{
IMPORTANT ASPECTS OF THE EXPERIMENTAL RESEARCH METHODOLOGY
}

\author{
Andrii Babii
}

\author{
Ternopil Ivan Puluj National Technical University, Ternopil, Ukraine
}

\begin{abstract}
Summary. Search agricultural machinery design, including wide spread boom sprayers is impossible to implement qualitatively without carrying out experimental investigations. Therefore, this paper is focused on the important aspects of preparation method for experimental research. Particularly, the analytical model for determining the approximation curve nature and the method of the calibration factor setting are given. The results of processing the experimental research oscillograph with reception of graphical dependences of normal tension in intersection of the investigated element of the metal construction are given.
\end{abstract}

Key words: rod sprayer, experimental research, approximation curve, strain gauge, strain gauge, stress.

Statement of the problem. The search design of agricultural machines, particularly long-range boom sprayers, is performed in several stages: problems analysis, development of ideas concerning improvement and its theoretical substantiation, experimental verification $[1$, 2]. And these are experimental investigations that deny or confirm the results of the research mathematical model of the particular object of the agricultural machine. Due to them the researcher obtains reliable background information about the object in order to develop adequate analytical models. Obtaining the most reliable magnitudes of the investigated values significantly depends on the quality of the set up and carried out experiment as well as on the processed results.

Analysis of the available investigations and publications. Experimental investigations of the development object is always followed by program design, writing methods, preparing the experimental equipment and the research object, immediate experiment directly and its results processing [3-6]. Each of these stages is important in order to obtain qualitative final result. There is a lot of information in the literature sources concerning the above mentioned problem, but, as a rule, it is presented only in general context and its adaptation to the particular experiment is very challenging.

One of the most important stages in the experiment preparation is the calibration of the strain gauge equipment. Methods of this procedure performance are described by researchers in many scientific papers, but there is little information about the mathematical apparatus of its implementation. In most cases, the final result is the calibration factor, and there is no evidence of its functional dependence.

Objective of the paper is to develop the method for strain gauge equipment calibration and provide the mathematical model for strain gauge resistance sensors calibration using rectangular beam loaded according to the «pure bending» scheme.

Statement of basic material. While carrying out the experimental investigations concerning the real stress state determining for metal structures of agricultural machines, particularly the boom frames of the long-range sprayers, strain gauges are often used. 
The same can be applied to various strain gauges, the basis of which is the sensitive element of the strain gauge. The deformation of this element depends on its resistance, and this affects the current circuit where it flows. Connecting to digital universal recording system (URS), we obtain the electrical signal, which due to the calibration procedure, is converted into physical value of the investigated parameter.

This method is presented on the example, of strain gauges P1calibration, which are selected from the lot of sensors stick to the sprayer metal structure.

P1 class sensors with B accuracy have the following technical parameters [7]:

- $\quad$ rated resistance: $200 \Omega$;

- $\quad$ boundary deviation of electrical resistance in the lot 100 pcs.: $\pm 0,2 \%$;

- $\quad$ maximum measured deformation: $\pm 3000 \mu \mathrm{m} / \mathrm{m}$;

- $\quad$ sensitivity: 1,9-2,3;

- $\quad$ operation temperature range: $-70^{\circ} \mathrm{C}$ to $+200^{\circ} \mathrm{C}$.

The strain gauge element is the rectangular steel (steel 25) beam with the cross section $8 \mathrm{~mm} \times 19 \mathrm{~mm}$ loaded with two symmetric forces forming constant bending moment area (pure bending).

Universal press UP-8 is the loading device, Figure 1.

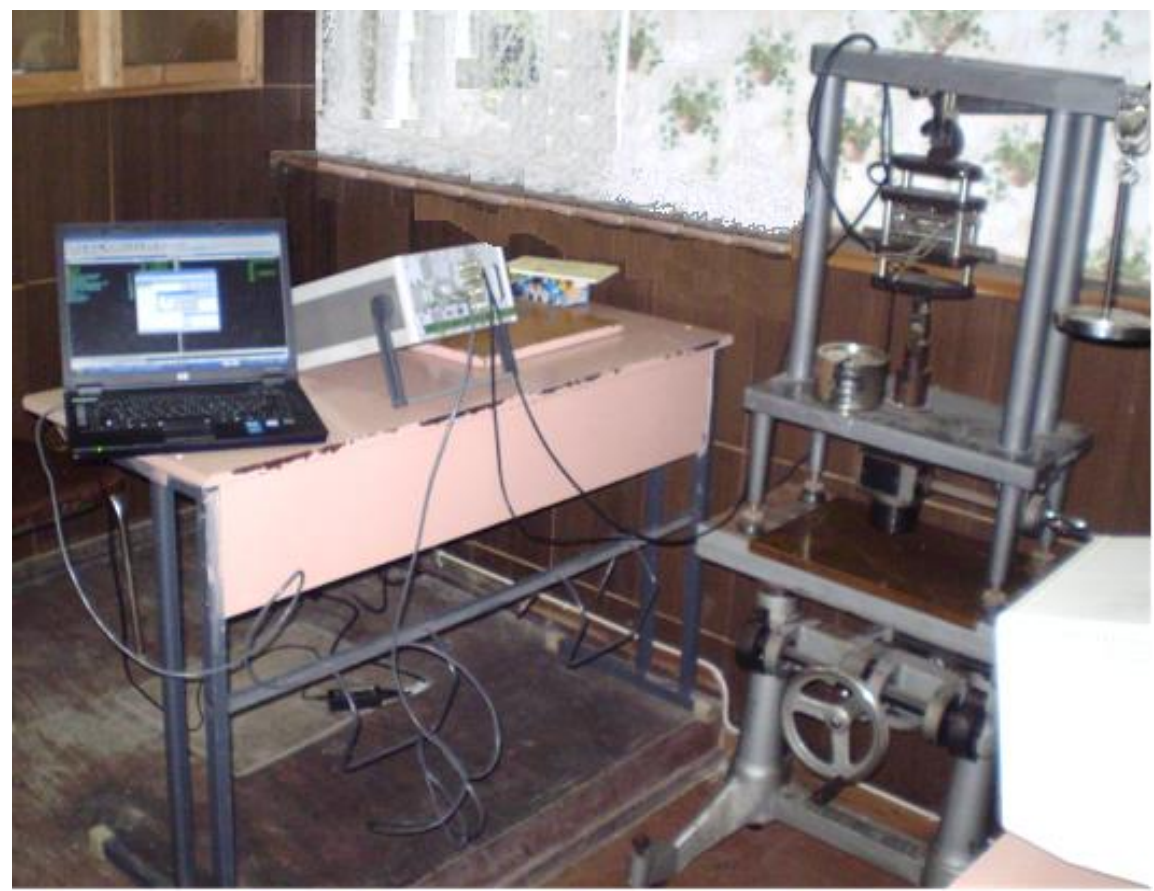

Figure 1. Strain gauge calibration at universal press UP-8

The given resistors are mounted on the top and bottom parts of the strain gauge beam (middle part) according to the standard procedure and by proper glue recommended by the strain gauges manufacturer. Then wire unsoldering is performed for connection to the SRU. The obtained strain gauge element is placed into the loading device included in the universal press UP-8. Distances between the supports $160 \mathrm{~mm}$, forces application prisms $70 \mathrm{~mm}$ (symmetrically from the beam middle of the) are provided. According to its design, UP-8 has force transmission coefficient $K=50$.

The calibration process itself is performed in the following sequence:

- connection of strain gauges to the corresponding SRU channel (channel 1 - resistor stick on the beam side, the fibers of the beam are stretched under load, channel 2 - the resistor on the compressed fibers); 
- $\quad$ procedure for SRU starting to the operation mode [8];

- gradual beam loading-unloading by means of universal press UP-8 (adding loads from $1 \mathrm{~kg}$ to $6 \mathrm{~kg}$ ). Multiplicity of carried out experiments is 3 .

According to the results of this calibration stage the following results are obtained, Table 1.

Table 1

The results of the strain gauge beam calibration in relative (electrical) units

\begin{tabular}{|c|c|c|c|c|c|c|c|c|}
\hline \multicolumn{2}{|c|}{ UP-8 load mass, $\mathrm{kg}$} & 0 & 1 & 2 & 3 & 4 & 5 & 6 \\
\hline \multirow{2}{*}{1} & $* \mathrm{R}_{1}$ & 2041 & 2103 & 2175 & 2252 & 2310 & 2370 & 2439 \\
\cline { 2 - 9 } & $* * \mathrm{R}_{2}$ & 2028 & 1949 & 1862 & 1821 & 1741 & 1670 & 1605 \\
\hline \multirow{2}{*}{2} & $\mathrm{R}_{1}$ & 2037 & 2108 & 2177 & 2255 & 2324 & 2369 & 2466 \\
\cline { 2 - 9 } & $\mathrm{R}_{2}$ & 2024 & 1932 & 1853 & 1815 & 1735 & 1682 & 1609 \\
\hline \multirow{2}{*}{3} & $\mathrm{R}_{1}$ & 2045 & 2112 & 2183 & 2264 & 2329 & 2375 & 2469 \\
\cline { 2 - 9 } & $\mathrm{R}_{2}$ & 2030 & 1948 & 1868 & 1825 & 1735 & 1685 & 1602 \\
\hline \multirow{2}{*}{$\begin{array}{c}\text { Avarage } \\
\text { values }\end{array}$} & $\mathrm{R}_{1}$ & 2041 & 2107 & 2178 & 2257 & 2321 & 2371 & 2485 \\
\cline { 2 - 8 } & $\mathrm{R}_{2}$ & 2027 & 1943 & 1861 & 1820 & 1737 & 1679 & 1605 \\
\hline
\end{tabular}

Note: $* \mathrm{R}_{1}$ is the line corresponding to channel 1 signals;

$* * \mathrm{R}_{2}$ is the line corresponding to channel 2 signals.

The final goal of calibration procedure for strain gauge sensors is to obtain the calibration coefficient providing SRU electrical signals conversion into physical magnitudes while investigating the real objects.

In order to choose further steps of the obtained statistic data processing, it is necessary to check the regularities of their placement on the coordinate plane. In other words, find their trends. Often, researchers accept, as a rule, the simplest trend without their choice substantiation. Let's also start with the simplest - the linear trend, which, logically, should reflect and continue the obtained values from the given series.

The trend construction essence is to determine the class of functions (among known ones) that can be most closely related to the point graphs of the experimental investigation time series. In order to determine the deviation of the specified function from valid experimental data, mainly the least-squares method is used.

To find the trend, the following mathematical apparatus is used.

General view of the empirical formula (trend) $[4,5]$

$$
y=f\left(t, a_{0}, \ldots, a_{m}\right), \quad m<k,
$$

where $m$ is the number of trend parameters, $k$ is the number of known time series values.

Trend deviation from the measured values during the experiment is

$$
\varepsilon_{i}=f\left(i, a_{0}, a_{1}, \ldots, a_{m}\right)-y_{i}, \quad i=1,2, \ldots, k
$$

The smallest squared sum of such deviations indicates the maximum convergence of the specified function and the corresponding points in the experimental data time series.

$$
S\left(a_{0}, a_{1}, \ldots, a_{m}\right)=\sum_{i=1}^{k} \varepsilon_{i}^{2}=\sum_{i=1}^{k}\left[f\left(i, a_{0}, \ldots, a_{m}\right)-y_{i}\right]^{2}
$$


It is know that in order to determine the function minimum $S\left(a_{0}, \ldots, a_{m}\right)$, in this case it is sufficient to find its partial derivatives by parameters $a_{0}, \ldots, a_{m}$ and set them to zero. Hence, we obtain the general notation of the equations system

$$
\left\{\begin{array}{l}
\frac{\partial S}{\partial a_{0}}=2 \sum_{i=1}^{k}\left[f\left(i, a_{0}, \ldots, a_{m}\right)-y_{i}\right] \cdot \frac{\partial f}{\partial a_{0}}=0 \\
\frac{\partial S}{\partial a_{m}}=2 \sum_{i=1}^{k}\left[f\left(i, a_{0}, \ldots, a_{m}\right)-y_{i}\right] \cdot \frac{\partial f}{\partial a_{m}}=0 .
\end{array}\right.
$$
equation

Now, taking into account the fact that the linear trend is described by the straight line

$$
y=a_{0}+a_{1} t
$$

from system (4) we obtain the system of linear algebraic equations for linear trend

$$
\left\{\begin{array}{l}
a_{0} k+a_{1} \frac{k(k+1)}{2}=\sum_{i=1}^{k} y_{i}, \\
a_{0} \frac{k(k+1)}{2}+a_{1} \frac{k(k+1)(2 k+1)}{6}=\sum_{i=1}^{k} i y_{i} .
\end{array}\right.
$$

It solution is found due to the known method by determining unknown coefficients $a_{0}$ and $a_{1}$. For this purpose, we write the known system parameters: $k=7 ; m=2 ; y_{i}$ is the average numerical values of time series $R_{1}$ of experimental investigations (Table 1).

After the substitution of the values, system (6) is as follows

$$
\left\{\begin{array}{l}
7 a_{0}+28 a_{1}=1,5733 \cdot 10^{4} ; \\
28 a_{0}+140 a_{1}=6,4854 \cdot 10^{4} .
\end{array}\right.
$$

The result of solution (7) is: $a_{0}=1,913 \cdot 10^{3}$ i $a_{1}=68,6429$.

Then the sought-for linear trend dependency is as follows

$$
y=1,913 \cdot 10^{3}+68,6429 t .
$$

Mean-square deviation is used to estimate the proposed trend quality

$$
\varepsilon=\sqrt{\frac{1}{k-m+1} \sum_{i=1}^{k} \varepsilon_{i}^{2}} .
$$

Here $\varepsilon=7,4849$.

Graphical interpretation of the carried out procedure is shown in Figure 2. 


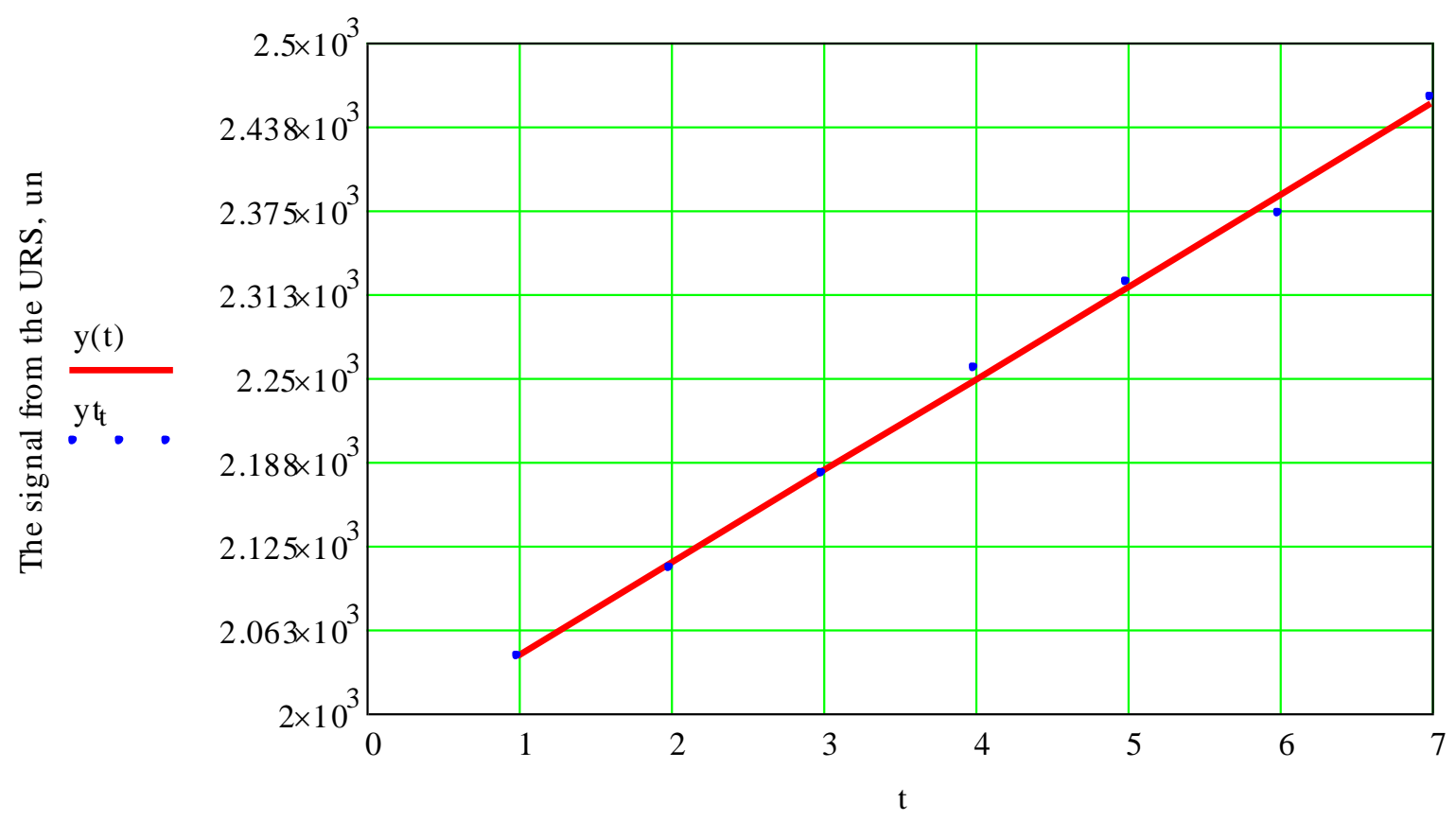

Degree of loading, N: 1-0;2-490,5; 3-981; 4-1471,5; 5-1962; 6-2452,5; 2943

Figure 2. Linear approximation of experimental time series data $R_{1}$

Similarly, we perform the described operations for statistical time series $R_{2}$ of electrical signals of resistor 2 .

System (6) according to the values of series $R_{2}$ is as follows

$$
\left\{\begin{array}{l}
7 a_{0}+28 a_{1}=1,2672 \cdot 10^{4} \\
28 a_{0}+140 a_{1}=4,877 \cdot 10^{4}
\end{array}\right.
$$

Hence we have: $a_{0}=2084,2857$ and $a_{1}=-68,5$.

Then the sought-for linear trend dependency is

$$
y=-68,5+2084,2857 t .
$$

Mean-square deviation is $\varepsilon=10,0865$.

Graphical interpretation is shown in Figure 3. 


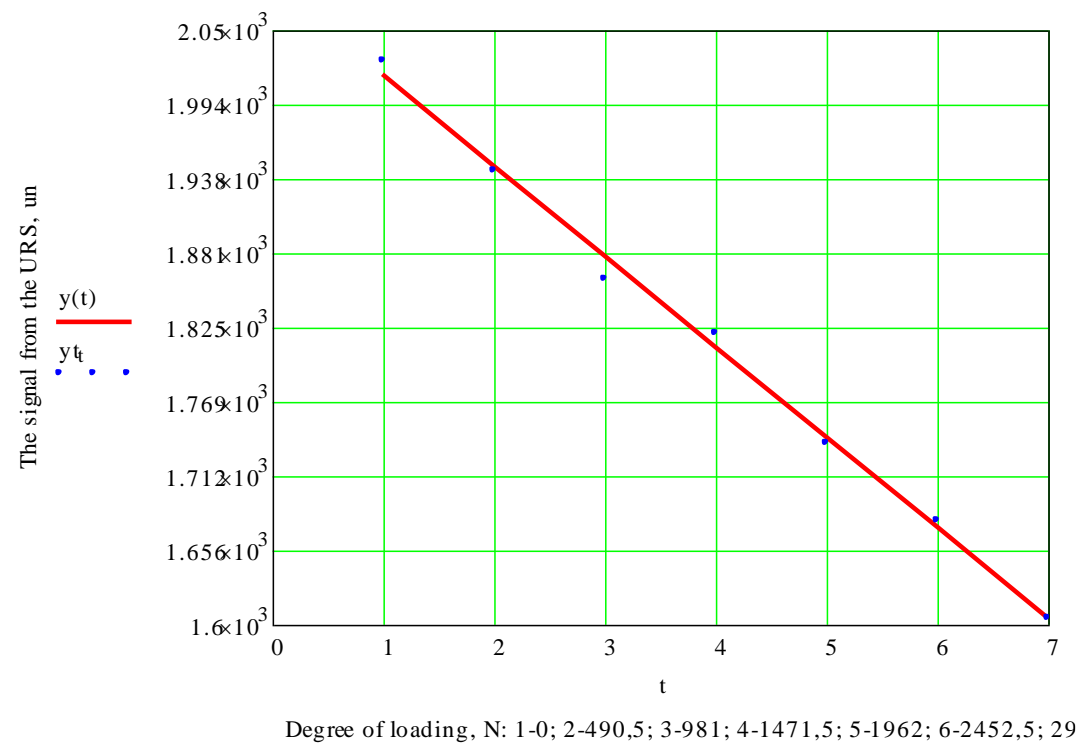

Figure 3. Linear approximation of experimental time series data $R_{2}$

It is evident from graphs in Figure 3, 4, that the experimental points scatter band probably has straight-line tendency, but it is reasonable to carry out comparative analysis, for example with quadratic trend, in order to substantiate the decision made.

The quadratic trend functional dependency is

$$
y=a_{0}+a_{1} t+a_{2} t^{2},
$$

then system (4) for parameter input $a_{0}, a_{1}, a_{2}$, is as follows

$$
\left\{\begin{array}{l}
a_{0} k+a_{1} \sum_{i=1}^{k} i+a_{2} \sum_{i=1}^{k} i^{2}=\sum_{i=1}^{k} y_{i}, \\
a_{0} \sum_{i=1}^{k} i+a_{1} \sum_{i=1}^{k} i^{2}+a_{2} \sum_{i=1}^{k} i^{3}=\sum_{i=1}^{k} i y_{i}, \\
a_{0} \sum_{i=1}^{k} i^{2}+a_{1} \sum_{i=1}^{k} i^{3}+a_{2} \sum_{i=1}^{k} i^{4}=\sum_{i=1}^{k} i^{2} y_{i} .
\end{array}\right.
$$

After substituting the mean values of series $R_{1}$, taking into account that $m=3$

$$
\left\{\begin{array}{l}
7 a_{0}+28 a_{1}+140 a_{2}=1,5733 \cdot 10^{4}, \\
28 a_{0}+140 a_{1}+784 a_{2}=6,4854 \cdot 10^{4} \\
140 a_{0}+784 a_{1}+4676 a_{2}=3,3 \cdot 10^{5} .
\end{array}\right.
$$

The determined coefficients are: $a_{0}=1968,7143 ; a_{1}=71,5 ; a_{2}=-0,3571$.

Functional dependence of quadratic trend is

$$
y=1968,7143+71,5 t-0,3571 t^{2} .
$$


Mean-square deviation is $\varepsilon=8,0686$.

Similarly, system (16) is obtained after substituting the average values of series $R_{2}$

$$
\left\{\begin{array}{l}
7 a_{0}+28 a_{1}+140 a_{2}=1,2672 \cdot 10^{4}, \\
28 a_{0}+140 a_{1}+784 a_{2}=4,877 \cdot 10^{4}, \\
140 a_{0}+784 a_{1}+4676 a_{2}=2,3818 \cdot 10^{5} .
\end{array}\right.
$$

The determined coefficients are: $a_{0}=2096,5714 ; a_{1}=-76,6905 ; a_{2}=1,0238$.

Then the functional dependence of quadratic trend is

$$
y=2096,5714-76,6905 t+1,0238 t^{2} .
$$

Mean-square deviation is $\varepsilon=10,2214$.

Let us compare the mean-square deviations for determined linear and quadratic trends for time series $R_{1}$ and $R_{2}$ :

- for series $R_{1}$ : mean-square deviations for linear trend is 7,4849; quadratic -8.0686 .

Here closer connection is provided by linear approximation;

- for series $R_{2}$ : for linear trend is 10,0865 ; quadratic - 10,2214.

It is evident from comparison that the mean-square deviation for both numerical series for linear approximation is smaller than quadratic one, and therefore it is reasonable to use linear dependence for the approximation of obtained numerical series $R_{1}$ and $R_{2}$.

If so, then for linear dependence the function increment is constant value. On this basis we develop method for determining the strain gauges calibration coefficient.

Using the known dependence from the strength of materials [9], the resistance moment of the experimental beam is

$$
W_{0}=\frac{b h^{2}}{6}
$$

where $b$ is beam width, $b=0,008 \mathrm{~m}$;

$h$ is beam height, $h=0,019 \mathrm{~m}$.

Then resistance moment is

$$
W_{0}=\frac{0,008 \cdot 0,019^{2}}{6}=4,8133 \cdot 10^{-7} \mathrm{~m}^{3}
$$

Theoretical normal stresses occurring in beam cross-sections are determined in the following way

$$
\sigma=\frac{M}{W_{0}}
$$

where $M$ is the moment occuring in the considered beam cross-section

$$
M=\frac{L_{A B}-L_{P}}{2} P,
$$


where $L_{A B}$ is distance between the supports $\mathrm{A}$ and $\mathrm{B}, L_{A B}=0,16 \mathrm{~m} ; L_{P}$ is distance between applied forces, $L_{P}=0,070 \mathrm{~m} ; P$ is force generated by UP-8 loading mechanism when changing loads and taking into account the force transfer coefficient $K=50$.

Accordingly, we obtain the moments by (20), by which the beam is loaded, N.m: 0; 22,$065 ; 44,13 ; 66,195 ; 88,26 ; 110,325 ; 132,39$.

Substituting the obtained moments into formula (19), we found the control values of normal stresses $\left(\sigma_{i}\right)$ in the beam cross-section intersection, where constant moment, MPa: 0; 45,$841 ; 91,683 ; 137,524 ; 183,365 ; 229,207 ; 275,048$ act.

In accordance with the strain gauges resistance and their sensitivity coefficient, as well as SRU operation mode, the signal gain by the equipment is, $k_{\text {pid }}=16$.

The discrete values of the calibration factor by signals of series $R_{1}$ and $R_{2}$ are determined by dependence

$$
k_{1(2) \operatorname{tar} i}=\frac{\sigma_{i} k_{p i d}}{R_{1(2) i}},
$$

the calculated values are summarized in Table 2.

Table 2

Discrete values of the calibration coefficient

\begin{tabular}{|c|c|c|c|c|c|c|c|}
\hline$k_{1 \text { tar } i}, \frac{\mathrm{MPa}}{u n .}$ & 0 & 0.3481 & 0.6734 & 0.9749 & 1.2640 & 1.5465 & 1.7904 \\
\hline$k_{2 \text { tar } i}, \frac{\mathrm{MPa}}{u n .}$ & 0 & 0.3775 & 0.7882 & 1.2088 & 1.6890 & 2.1842 & 2.7413 \\
\hline
\end{tabular}

The gain of the relative units values for SRU electrical signal on sections $i=1,2, \ldots, k-1$ under gradual loading of the investigated beam is determined by the following dependence

$$
\Delta_{1(2) i}=R_{1(2) i+1}-R_{1(2) i}
$$

Average gain is

$$
\Delta_{1(2)}=\frac{\sum_{i=1}^{k}\left(R_{1(2) i+1}-R_{1(2) i}\right)}{k-1} .
$$

The determined values by dependences (22) and (23) are summarized in Table. 3.

Table 3

Average gain

\begin{tabular}{|c|c|c|c|c|c|c|c|}
\hline$\Delta_{1 i}$ & 66 & 71.33 & 78.67 & 64 & 50.33 & 86.67 & $\Delta_{1}=69,5$ \\
\hline$\Delta_{2 i}$ & -84.33 & -82 & -40.67 & -83.33 & -58 & -73.67 & $\Delta_{2}=-70,33$ \\
\hline
\end{tabular}


The average gain in sections by the values of series $R_{1}$ and $R_{2}$, that is, on stretched and compressed fibers, is $\Delta=69,92$, the ratio error between the average gain is $1.2 \%$.

Let us determine the averages of the calibration factor by average gain and based on the stresses values determined from (21) for both series

$$
k_{1(2) T i}=\frac{\sigma_{R 1(R 2)_{i+1}}-\sigma_{R 1(R 2)_{i}}}{\Delta} k_{p i d}
$$

where $\sigma_{R 1(R 2)_{i}}$ are stresses determined from (21) based on numerical values of series $R_{1}$ and $R_{2}$.

Substituting the numerical values into (24), we obtain identical values of the calibration factor for all sections and for both series $k_{1(2) T}=k_{T}=10,4905 \frac{\mathrm{MPa}}{\mathrm{un}}$.

Conclusion. The obtained value of calibration factor is used to transform the electrical signal values (in relative units) to the actual stress values. The result of such procedure is shown in Figure 4 and 5.

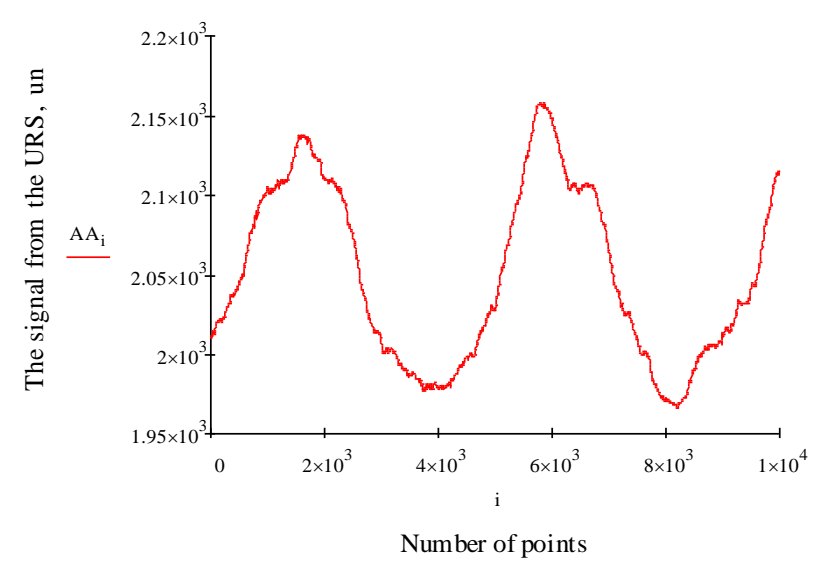

Figure 4. The component of unprocessed oscillogram (5s) of the experimental sprayer investigation

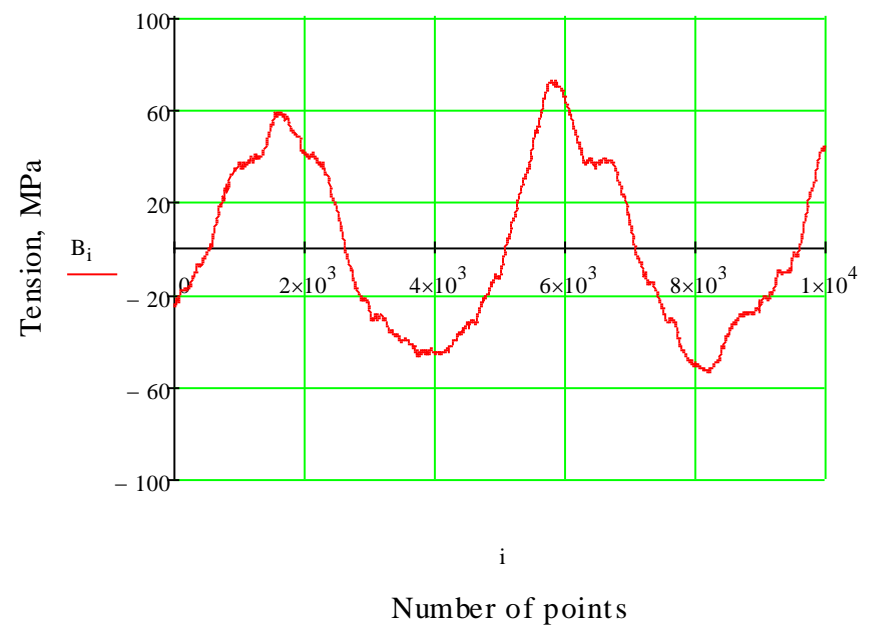

Figure 5. The nature normal stresses change in the investigated cross-section of metal construction according to the obtained oscillogram 
The component of the oscillogram of stress state investigation for one of the boom frame cross-sections of the long-rande sprayer during the technological process implementation is shown in Figure 5. And the processed signal, where the result of dynamic loads action given in physical units - stresses in MPa is shown in Figure 6. Thus, according to the obtained actual values, such as acting stresses, the prediction of the operational life for the given metal structures is done. The results of such investigations are given in papers [10-12].

\section{References}

1. Rybak T., Babiy A., Popovych P. Prohnozuvannya resursu roboty mobil'nykh sil's'kohospodars'kykh mashyn na osnovi tryyedynoyi modeli optymal'noho konstruyuvannya. Visnyk TNTU. 2011. Vol. 16. No. 3. P. 77-85.

2. Rybak T. I., Babiy A. V., Ripets'kyy Ye. Y. Tryyedyna model' poshukovoho konstruyuvannya sil's'kohospodars'kykh mashyn. Svidotstvo pro reyestratsiyu avtors'koho prava na tvir. No. 33031. Data reyestratsiyi 29.04.2010 r.

3. Pohorelyy L. V. Ynzhenernыe metodы yspыtanyy sel'skokhozyaystvennыkh mashyn. K.: Tekhnika, 1981. $176 \mathrm{p}$.

4. Astakhova L. H. Matematycheskaya teoryya planyrovanyya эksperymenta: metodycheskye ukazanyya. Vladykavkaz: Terek, 2014. 77 p.

5. Hrabar I. H., Vodyanyts'kyy H. P. Teoriya ta tekhnolohiya naukovykh doslidzhen': navchal'nyy posibnyk dlya mahistriv napryamu pidhotovky: 8.10010203 «Mekhanizatsiya ta elektryfikatsiya sil's'koho hospodarstva», «Avtomobili ta avtomobil'ne hospodarstvo». ZhNAEU, 2013. 260 p.

6. Adler Yu. P., Markova E. V., Hranovskyy Yu. V. Planyrovanye эksperymenta pry poyske optymal'nыkh uslovyy. M.: Nauka, 1976. 279 p.

7. VEDA. URL: http://veda.com.ua/catalogue/tenzorezistory/odinochnyi/1.html.

8. Rybak T. I., Pidhurs'kyy M. I., Kostyuk V. I., Teslenko V. O., Zaluzhnyy V. I. Universal'na vymiryuval'na systema dlya doslidzhennya dynamiky sil's'kohospodars'kykh mashyn. Nadiynist' i dovhovichnist' mashyn i sporud. 2005. Vol. 25. P. 112-119.

9. Pysarenko H. S., Yakovlev A. P., Matveev V. V. Spravochnyk po soprotyvlenyyu materyalov. K.: Nauk. dumka, 1988. $736 \mathrm{p}$.

10. Andreykiv O. Ye., Babiy A. V., Dolins'ka I. Ya., Matviyiv Yu. Ya. Vyznachennya zalyshkovoho resursu shtanhy pol'ovoho obpryskuvacha za manevrovoho rezhymu navantazhennya. Fiz.-khim. mekhanika materialiv. 2020. No. 1. P. 106-111.

11. Babii A., Babii M. Impact of oscillation amplitude of boom sprayers load-bearing frame sections. Scientific Journal of TNTU. 2019. Vol. 95. No 3. P. 97-104. https://doi.org/10.33108/visnyk_tntu2019.03.097

12. Rybak T. I., Babii A. V., Bortnyk I. M. et al. Evaluation of the Service Life of the Frames of Sections of Boom Field Sprayers. Mater Sci 55. 2019. P. 374-380. https://doi.org/10.1007/s11003-019-00312-0

\section{Список використаної літератури}

1. Рибак Т., Бабій А., Попович П. Прогнозування ресурсу роботи мобільних сільськогосподарських машин на основі триєдиної моделі оптимального конструювання. Вісник ТНТУ. 2011. Том 16. № 3. C. 77-85.

2. Рибак Т. І., Бабій А. В., Ріпецький Є. Й. Триєдина модель пошукового конструювання сільськогосподарських машин: свідоцтво про реєстрацію авторського права на твір №33031; дата реєстрації 29.04.2010 p.

3. Погорелый Л. В. Инженерные методы испытаний сельскохозяйственных машин. К.: Техніка, 1981. $176 \mathrm{c}$.

4. Астахова Л. Г. Математическая теория планирования эксперимента: методические указания. Владикавказ: Терек, 2014. 77 с.

5. Грабар І. Г., Водяницький Г. П. Теорія та технологія наукових досліджень: навчальний посібник для магістрів напряму підготовки: 8.10010203 «Механізація та електрифікація сільського господарства», «Автомобілі та автомобільне господарство». ЖНАЕУ, 2013. 260 с.

6. Адлер Ю. П., Маркова Е. В., Грановский Ю. В. Планирование эксперимента при поиске оптимальных условий. М.: Наука, 1976. 279 с.

7. ВЕДА. URL: http://veda.com.ua/catalogue/tenzorezistory/odinochnyi/1.html.

8. Рибак Т. І., Підгурський М. І., Костюк В. І., Тесленко В. О., З Залужний В. І. Універсальна вимірювальна система для дослідження динаміки сільськогосподарських машин. Надійність i довговічність машин і споруд. 2005. Вип. 25. С. 112-119.

9. Писаренко Г. С., Яковлев А. П., Матвеев В. В. Справочник по сопротивлению материалов. К.: Наук. думка, 1988. 736 с. 
10. Андрейків О. Є., Бабій А. В., Долінська І. Я., Матвіїв Ю. Я. Визначення залишкового ресурсу штанги польового обприскувача за маневрового режиму навантаження. Фіз.-хім. механіка матеріалів. 2020. № 1. С. 106-111.

11. Babii A., Babii M. Impact of oscillation amplitude of boom sprayers load-bearing frame sections. Scientific Journal of TNTU. 2019. Vol. 95. No 3. P. 97-104. https://doi.org/10.33108/visnyk_tntu2019.03.097

12. Rybak T. I., Babii A. V., Bortnyk I. M. et al. Evaluation of the Service Life of the Frames of Sections of Boom Field Sprayers. Mater Sci 55. 2019. P. 374-380. https://doi.org/10.1007/s11003-019-00312-0

\title{
УДК 631.3.05
}

\section{ВАЖЛИВІ АСПЕКТИ МЕТОДИКИ ПРОВЕДЕННЯ ЕКСПЕРИМЕНТАЛЬНИХ ДОСЛІДЖЕНЬ}

\author{
Андрій Бабій
Тернопільський національний технічний університет імені Івана Пулюя, Тернопіль, Україна

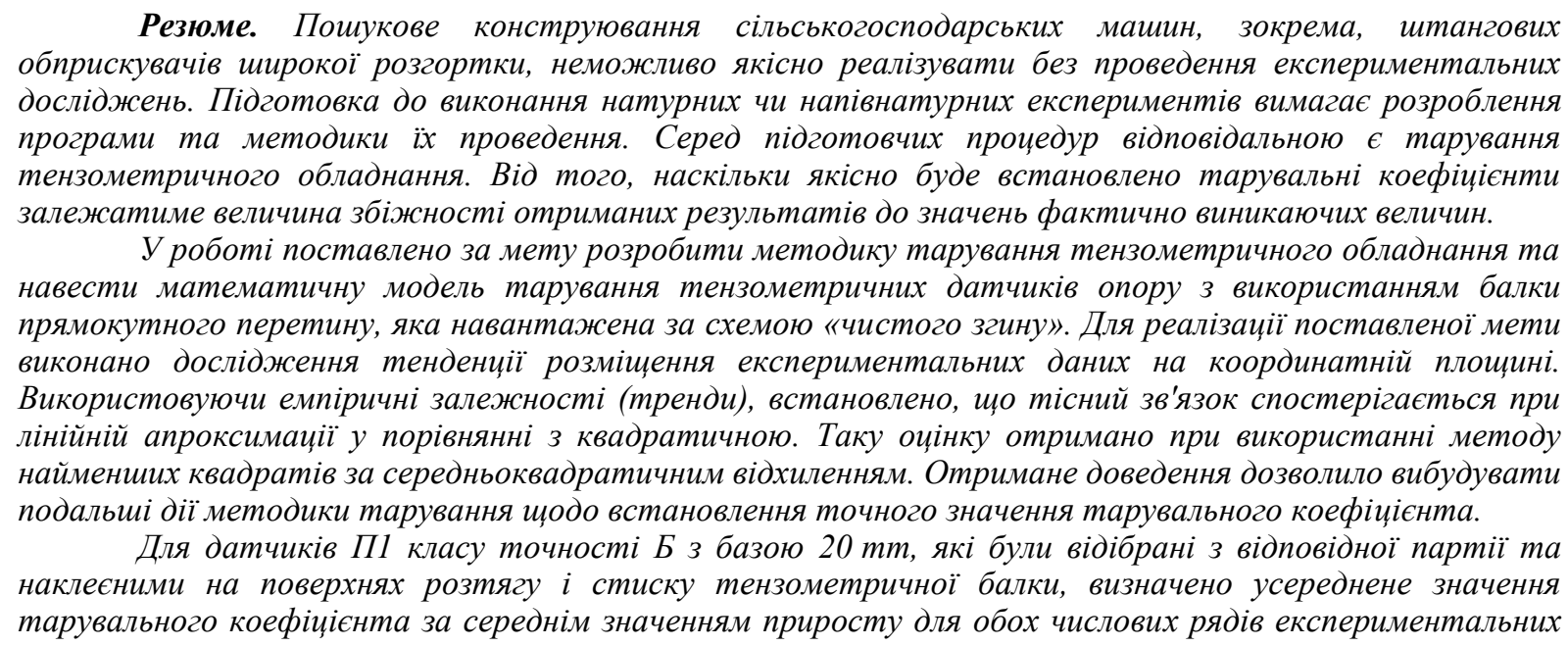
даних. При изьому тарувальний коефіиієнт становить $k_{1(2) T}=k_{T}=10,4905 \frac{\mathrm{MPa}}{u n .}$. Отримане значення даного коефіцієнта використовується для переведення значень електричного сигналу (у відносних одиницях) осиилограми експериментального дослідження у фактичні значення діючих напружень чи інших фізичних величин.

Ключові слова штанговий обприскувач, експериментальні дослідження, апроксимуюча крива, тензорезистор, момент опору, напруження. 